\title{
Planning Exhibition Activities of Coal Mining Enterprises
}

\author{
Natalya Dmitrieva ${ }^{1, *}$, Olga Gabinskaya $^{1}$, and Galina Chistyakova ${ }^{1}$ \\ ${ }^{1}$ Plekhanov Russian University of Economics, Kemerovo Institute (branch), 650992 Kuznetsky Av. \\ 39, Kemerovo, Russia
}

\begin{abstract}
The development programs of coal mining enterprises pay special attention to the increase in production potential and the penetration of new market niches, as well as the organization of rational interaction with related industries. The creation of clusters in such conditions contributes to the sustainable development of the region. The exhibition activities of coal mining enterprises play an important role in establishing rational interaction with companies of coal and related industries, thus creating favorable conditions for the modernization of Russian coal mining and processing enterprises. The article focuses on the pre-show stage of the exhibition activity of coal mining enterprises devoted to planning and preparing for the exhibition event. The series of decisions made during the stage include setting goals of participation, choosing the exhibition event, determining the form of participation, designing the stand, planning onstand and off-stand activities, preparing information, advertising and souvenir materials, recruiting and training of the exhibition staff.
\end{abstract}

\section{Introduction}

The growth of coal production of recent years is certainly a great advantage for the Russian economy as a whole and for Kuzbass in particular. Revenues to the regional budget from coal enterprises are about $20 \%$ and their increase is the key to sustainable development of the region. The 2017 results for the Russian coal industry can be assessed as positive. In 2017 the main driver of growth in coal production remained exporting. According to the data of Analytical Center for the Government of the Russian Federation (January, 2018), coal production for 2017 increased by $6.2 \%$ (compared to 2016) with an increase in exports by $12.4 \%$. The growth of prices for coking coal continued while prices for energy coal being stable. The increase in the cost of coking coal (up to 27\%) was significantly influenced by the continued high demand from Asian countries, mainly China and the Republic of Korea. The price increase was also affected by unstable Australian mining industry suffered from cyclones. The price of energy coal remained generally at the same level, increasing by an average of $1 \%$.

One of the objectives of the Long-term Program for Coal Sector Development of Russia until 2030 (the Decree of the Government of the Russian Federation of June 12, 2014, №1099-p) is to create an "environment for the development" of coal enterprises, that pro-

* Corresponding author: dmitrievanv@yandex.ru 
vides an opportunity to implement the most promising innovative projects to strengthen its production capacity and for coal products to penetrate new market niches; as well to organize rational interaction with related industries. Clusters being created contribute to the sustainable development of the region [1]. In the current conditions, the exhibition activity of coal enterprises after the recent downturn has all the prerequisites for activation. Modern exhibitions are a platform for interaction of all sectors of the mining industry; they allow introducing a wide range of equipment, technologies for coal production, and new products from manufacturers of mining, processing, mineral processing, electromechanical, lighting equipment, and safety facilities. Participation in exhibitions serves as an effective tool for communication of world-class experts, discussion of industry development prospects, creation of favorable conditions for modernization of Russian coal mining and coal processing enterprises.

\section{Materials and methods}

Materials for the research are the data on exhibition activities of coal mining and coal processing enterprises. The authors used several methods of sociological and marketing research including observation, content analysis, personal in-depth interviews with top managers and PR specialists of coal enterprises, and methods of statistical analysis.

\section{Results and discussion}

Participation in exhibitions involves compliance with a certain algorithm of actions that can be divided into three stages - pre-show, at-show, and post-show [2]. The reason is that trade show is such an activity that requires differentiated firm activities, resources and marketing approaches from the time the decision to participate at a certain trade show until the end of the trade show [3]. A three stage process of the trade show has been used in many research studies in order to show the importance of each activity and the stage it belongs [4-6]. Activities intended for implementing at each stage are presented in Table 1.

Table 1. Stages of exhibition activity of enterprises.

\begin{tabular}{|c|c|}
\hline Stage & Activities \\
\hline Pre-show & $\begin{array}{l}\text { Defining objectives of participation } \\
\text { Choosing the exhibition } \\
\text { Determining the form of participation } \\
\text { Designing the stand* } \\
\text { Planning stand events* } \\
\text { Preparing information, advertising and souvenir materials } \\
\text { Planning off-stand activities } \\
\text { Recruiting and staff work planning }\end{array}$ \\
\hline At-show & $\begin{array}{l}\text { Stand fitting* } \\
\text { Holding stand events* } \\
\text { Off-stand activities }\end{array}$ \\
\hline Post-show & $\begin{array}{l}\text { Processing and systemizing the data received } \\
\text { Assessing participation effectiveness }\end{array}$ \\
\hline
\end{tabular}

Planning and preparation for the exhibition form one of the most important stages, which largely determines the success of participation. The researchers mention that properly planned exhibition events may lead to the direct sales, as well as the development of the brand image or building the brand awareness; penetration of new markets; trials of new products and knowledge diffusion. These business goals might be future-focused, with meetings of strategic players from across an industry or sector contributing to the shaping 
of future innovations and development. Industrial events act as a marketplace, but rather than seeing them as temporary or isolated activities, they can be understood as cyclical clusters [7].

Let's consider the activities of the pre-show stage, taking into account the specifics of coal mining enterprises.

The main objective of participation in the exhibition is traditionally the search for new customers and business partners, cooperating with which will allow increasing production and sales of goods. However, nowadays exhibitions of the fuel and energy complex provide interaction of both mining and processing companies as well as supplying companies (mechanical engineering, transport, automation, security, production of safety equipment, etc.). Therefore, searching for business partners that can contribute to the increase in production efficiency as well as studying and assessing competing companies are the goals of great importance.

Being mainly aimed at promoting their products, coal mining enterprises pay much attention to matters connected with reducing the negative impact on the environment. At trade shows coal mining and coal processing enterprises exhibit waste water treatment technologies, land reclamation projects, measures to reduce dust emissions, coal mining machinery development, etc. [8-11]. Enterprises also exhibit events on improving occupational and industrial safety management system, and other socially oriented projects [12]. All this has a direct impact on the sustainable development of the region (Figure 1).

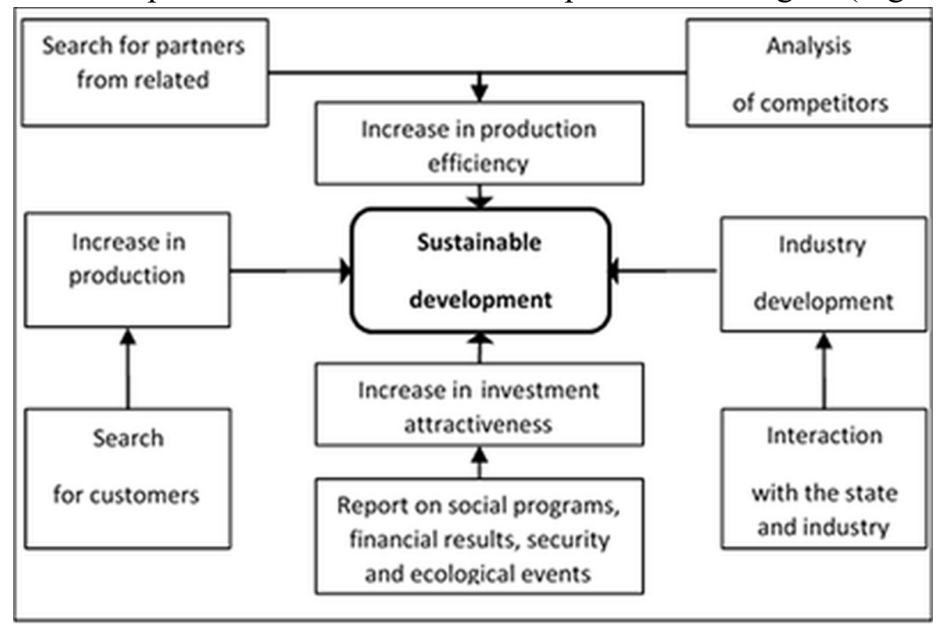

Fig. 1. The role of exhibition activity in the sustainability of mining region.

The choice of the exhibition event is directly related to the goals of participation. Due to the fact that almost all modern industrial exhibitions are innovative and are accompanied by near-exhibition events of strategic, scientific and technical nature, exhibitors should radically change their approach to the choice of the exhibition and the organization of exhibition activities, as participation in the exhibition in order to promote the product, maintain the image and other purely marketing purposes become ineffective. It is necessary to make the full use of the potential of exhibitions as centers forming trends of industry development, new standards of quality, development of network business models, the system of publicprivate partnership, etc.

According to the Russian Coal Journal "Ugol" data, in 2018, coal mining enterprises can take part in 53 exhibitions, fairs and conferences on mining topics, including 22 events on the territory of the Russian Federation, and 10 events in the CIS countries. Most of the 
exhibitions are international in nature. The main criteria when choosing an exhibition should be the following:

- the estimated number of visitors;

- the structure of exhibitors in terms of participation of competing enterprises (the indicator of exhibition attractiveness), possible business partners, i.e. companies from related industries (the possibility of increase in production efficiency), and the number of countries participating;

- the program of exhibition events (conferences, roundtable discussions, symposiums, presentations, etc.);

- the participation costs (transport costs, exposition costs, rents and other contributions to the organizers, promotional materials and souvenir products, wages and other staff costs).

To make the final choice it is advisable to compare several exhibition events according to the criteria specified in Table 2. The information for comparison is usually available on the official websites of the exhibition organizers; otherwise, it can be directly requested. The refusal to provide the information is indicative of low level of the exhibition event.

Table 2. Comparison of exhibition events, 2017 (the organizers' data).

\begin{tabular}{|c|c|c|}
\hline Selection criteria & $\begin{array}{c}\text { MiningWorld Central } \\
\text { Asia, Kazcomak, } \\
\text { Metaltech CAh, 2017 } \\
\text { (Kazakhstan, Astana) }\end{array}$ & $\begin{array}{c}\text { Coal of Russia and } \\
\text { Mining. Resources of } \\
\text { Russia. Safety and } \\
\text { Health, 2017 (RF, } \\
\text { Novokuznetsk) }\end{array}$ \\
\hline Number of visitors & more than 2000 & 35512 \\
\hline $\begin{array}{c}\text { Number of countries } \\
\text { participating }\end{array}$ & 28 & 24 \\
\hline Number of exhibitors & 271 & 614 \\
\hline $\begin{array}{c}\text { Numbers of exhibition } \\
\text { events }\end{array}$ & 8 & 38 \\
\hline
\end{tabular}

To check the information from organizers one can apply to independent specialists, for example, the Authorized company-auditor of exhibition statistics "RussCom IT Systems", working under control of the Russian Union of Exhibitions and Fairs.

Depending on the goals set and the exhibition event chosen, the form of participation in the exhibition is determined:

- placement on an individual standard stand;

- placement on an individual branded stand with exhibits on the profile of the exhibition, with an office room for negotiations;

- participation in the collective exposition of the group (representatives of the country, region, group of companies) with holding presentations, seminars, roundtable discussions during the exhibition;

- participation with advertising and information stand with projects, catalogs, reference and information literature, advertising films and packages of business offers;

- participation as a visitor ("a business visit") with the opportunity to participate in all events held during the exhibition;

- remote participation of the enterprise with placement of the information in the exhibition catalogue and distribution of advertising and information materials of the enterprise at the exhibition.

In recent years, the process of selling coal has undergone significant changes. The development of tender trade and its telecommunication support, improvement of standardization, expertise and certification of coal led to the decrease in the role of personal contacts in organization of sales. Therefore, coal mining and processing enterprises are much less likely than before to choose an individual stand, preferring other forms of participation listed 
above. At the same time, an individual stand allows solving a wider range of problems that are associated both with selling goods and attracting investors and business partners, as well as strengthening the company's image.

Properly designed stand (pavilion) largely determines the effectiveness of participation in the exhibition. Modern researchers suggest using nine Pavilion quality factors - Outline of pavilion, Features of pavilion, Operating features of pavilion promotional booth, On-site promotional activities of the exhibitor, Expertise of booth operating personnel, Exhibitor's booth-equipment level, Trade-meeting support, Local promotional activities by the pavilion organizer, General information [13]. Designing the stand should start with determining its type (Row stand, Walk-through stand, Corner stand, Peninsula stand, etc.); location (near to the entrance door and/or crowded places); and stand area (depending on the planned exhibit). The products of coal mining enterprises can hardly be used as a basis for design of the exhibition stand as it usually done by the companies from other industries. That's the reason for proper planning solutions (frame or frameless stand), the quality of the materials used, the presence of presentation equipment, and specialized lighting to be of great importance. Thus, standard stands offered by the organizers of exhibitions rather negatively affect the image of a large enterprise. Currently, there is a wide range of possibilities to create truly individual stands of MDF, wood chipboard, aluminum, steel, acrylic glass, PVC plastic, various vinyl fabrics and other materials that can be used several times. This significantly reduces the costs of participation in exhibitions, in case the company is engaged in exhibition activities regularly.

Due to the "low informative products" phenomenon coal mining enterprises should also pay much attention to planning stand events. The events can include a meeting with the management and specialists of the enterprise, demonstration of the film about the features of the enterprise and its production process, presentation of products, etc. For planning bringing good results, it is important to have the information about the structure of the visitors, their interests and competencies. The planned events should be announced in advance, they can become an additional factor attracting visitors to a particular stand.

Preparation of information, advertising and souvenir materials in coal industry involves working with a wide range of them. Unlike other areas, it is almost impossible to use illustrated product catalogs and flyers as the main tool. Also the role of classical souvenir production is reduced. For a decent presentation, the enterprise needs to prepare a sufficient amount of documentary evidence of product quality, expert reports, evidence of achievements, development plans and other similar materials, possibly formalizing them all together in the form of a modern prospectus.

Planning off-stand activities involves a preliminary detailed study of the exhibition program in order to maximize the coverage of useful events (meetings with authorities, roundtable discussions, conferences, symposiums, presentations, excursions, etc.). The Exhibitor may initiate such events independently, having previously (usually six months or more before the start of the exhibition) agreed with the organizers of the exhibition on their content. Off-stand activities have an impact on the last component of planning - staff recruiting and training.

Training of coal enterprises' staff to work at the exhibition is also somewhat specific. As there are practically no direct sales, classical trainings on developing sales skills are often ineffective. As K. S. Söilen mentions, researches also show that much current formal training functions so as to reduce contact time between booth staff and visitors, but does not lead to higher sales. That could be because training often focuses mainly on technical aspects of products rather than on relational aspects. Booth staff are often unable to distinguish between visitors who are seeking to buy the product and those who have come to the booth for other reasons. Or, putting it another way, the trainers themselves do not always understand the complexity of booth staff behaviour. Ordinary sales training does not offer 
much help to those who staff exhibition booths. Booth staff have to practise two kinds of behaviour, selling and non-selling/promotional, and they need to be able to distinguish between a number of different types of agent with different needs. These are things that ordinary sales training does not cover. They imply that the company should have at least two sets of objectives: one for its selling and one for its non-selling activities [14].

The involvement of the third-party promotional staff widespread in other areas is also controversial. For coal enterprises it is extremely important for the stand staff to be able to communicate professionally with visitors. It often requires a great depth of specialized knowledge achieved not by training, but the relevant experience. It is desirable that at least middle-level managers should be involved as the stand staff. According to modern approaches to the management of coal enterprises staff they should have not only professional knowledge and skills, but also such competencies as Organization Coordination, Customer Orientation, and Communication Influence [15].

\section{Conclusion}

Participation of coal mining enterprises in exhibitions is directly connected with the sustainable development of the region, as in addition to the main goal - the increase in sales of coal and its derivatives - it allows getting acquainted with the latest achievements of related industries and considering the possibility of their use, that results in the increase in production efficiency. Demonstrating socially oriented and environment-friendly projects, events on safety and improvement of working conditions, coal mining enterprises increase their investment attractiveness and strengthening relations with authorities. The exhibitions facilitate the processes of exchanging information and making joint decisions on the industry development. All this ultimately has a direct impact on the sustainable development of the region.

Planning the exhibition activities by coal mining enterprises has its own specifics, which consists in diversity of goals, a wide choice of exhibition events, the complexity of creating an effective exhibition area, a great role of on-stand and off-stand events, special requirements for the exhibition staff training. Paying proper attention at the planning stage to the aspects mentioned will allow coal mining enterprises to improve the efficiency of exhibition activities.

\section{References}

1. S. Zhironkin, M. Gasanov, G. Barysheva, E. Gasanov, O. Zhironkina, G. Kayachev, E3S Web of Conferences, 21, 04002 (2017)

2. E. Çobanoğlu, V. Turaeva, Procedia - Social and Behavioral Sciences, 150, 762-771 (2014)

3. F. H. R Seringhaus, P. Rosson, Problems and Perspectives in Management, 2:4, 152165 (2004)

4. J. F. Tanner, Industrial Marketing Management, 31, 229-239 (2002)

5. L. Li, Industrial Marketing Management, 35, 166-177 (2006)

6. C. H. Lee, S. Y. Kim, Industrial Marketing Management, 37:7, 784-796 (2008)

7. F. Warwick, J. Laing, Exhibitions, Trade Fairs and Industrial Events (ACTA, Routledge, 2017)

8. A. Sushko, Yu. Filatov, M. Kislyakov, I. Kislyakov, IOP Conf. Series: Earth and Environmental Science, 50, 012012 (2017) 
9. T. Gvozdkova, M. Tyulenev, S. Zhironkin, V. A. Trifonov, Yu. M. Osipov, IOP Conf. Series: Earth and Environmental Science, 50, 012010 (2017)

10. A. B. Efremenkov, A.A. Khoreshok, S.A. Zhironkin, A.V. Myaskov, IOP Conf. Series: Earth and Environmental Science, 50, 012009 (2017)

11. M. I. Agienko, E. P. Bondareva, G. V. Chistyakova, O.V. Zhironkina, O. I. Kalinina, IOP Conf. Series: Earth and Environmental Science, 50, 012022 (2017)

12. S. Smagina, O. Kadnikova, K. Demidenko, G. Chistyakova, A. Rolgayzer, E3S Web of Conferences, 21, 04020 (2017)

13. Ki-Kwan Yoon, So-Sun Lim, Mi-Na Parkc, Procedia - Social and Behavioral Sciences, 40, $681-688$ (2012)

14. K. S. Söilen, Exhibit Marketing and Trade Show Intelligence, Successful Boothmanship and Booth Design (New York, Springer Science \& Business Media, 2013)

15. Xu Hong-huaa, Wang Yan-huab Procedia - Earth and Planetary Science, 1, 1764 1771 (2009) 